\title{
JAPAN'S AGRICULTURAL CALCULATION OF THE TRANS-PACIFIC PARTNERSHIP AGREEMENT NEGOTIATIONS
}

\author{
Jian Ma and Alias Abdullah
}

Following the victory in the senate election in July 2013, the leader of the Liberal Democratic Party (LDP) Shinzo Abe ended the situation of disordered congress and controlled the required seats that ensured the stability of the LDP regime in the next three years. Meanwhile, much attention was focused on the new government as questions loomed on the important issue of whether Japan will eventually join the Trans Pacific Partnership (TPP) or not. In November 2010, at the Asia-Pacific Economic Cooperation (APEC) summit, the former Japanese Prime Minister Naoto Kan announced that Japan would negotiate with relevant countries about the possibility of Japan joining the TPP; his statement triggered immediate controversy and heated discussions among different local interest groups. Among them, the strongest opposition was the Japan Agricultural Cooperatives (JA) and farmers who had close relations with JA. Nevertheless, Japan's Premier Shinzo Abe resisted the pressure from the LDP and domestic opposition groups; he announced the official entry of Japan into the TPP negotiations on 15 March 2013. However, the LDP is supported by Japanese farmers and it is very important to take farmers' votes into consideration. A few controversial questions arise: Does Shinzo Abe not care? After joining the TPP, will Japan's agriculture be threatened and collapse as the JA has said? This paper will discuss Japan's agricultural outlook of TPP negotiations based on the analysis of the status and issues of Japanese agriculture.

\section{Introduction}

The Trans-Pacific Partnership Agreement, is an evolving regional free trade agreement (FTA). It was originally formed as the Trans-Pacific Strategic Economic Partnership, an FTA now in effect between Singapore, New Zealand, Chile, and Brunei (the so-called "P-4") since 2006. In the fall of 2008, the United States, along with Australia, Peru, and Vietnam, joined the negotiations to accede to the arrangement. Malaysia joined as the ninth negotiating partner in October 2010. ${ }^{1}$ In 2012, Mexico and Canada became the tenth and the eleventh negotiation members in the TPP.

Over the past decade, the number of bilateral and regional Free Trade Agreements (FTAs) has increased substantially, a trend that Japan has followed by signing a host of such agreements, which it prefers to call them Economic Partnership Agreements (EPAs). ${ }^{2}$ The EPA's principle is to harmonize non-tariff barriers among the member countries, based on the FTA's principle. Japan has established EPA, not FTA for agricultural protection, for commodities such as rice and other staple foods. Japan's

\footnotetext{
1 Cooper William and Mark E. Manyin, "Japan Joins the Trans-Pacific Partnership: What Are the Implications?" Congressional Research Service Report for Congress, 2013, pp 1-19.

2 Chris Clague, "Special Report: Japan, the TPP, and Agriculture," 2011, pp 1-9.
} 
first EPA was known as "Japan-Singapore EPA" in 2001. ${ }^{3}$ Until 2012, Japan had already signed another 12 EPAs with Mexico, Malaysia, Chile, Thailand, Indonesia, Brunei, Philippines, ASEAN, Switzerland, Vietnam, India and Peru.

\section{The Japanese Government and the TPP}

\section{The Attitude of the Japanese Government toward TPP Negotiations}

On 14 November 2010 at the APEC press conference, Naoto Kan, the former prime minister of Japan, said that Japan's agriculture sector was weak at that time and the government would revive it; however, at the same time the country would work on economic partnerships and liberalization endeavors. They planned to open up Japan in the 21st century. This triggered a conflict of domestic opinions between industrial sectors and agricultural sectors in Japan.

On 11 November 2011, Japan's Prime Minister Yoshihiko Noda officially announced the country's stance on the free-trade initiative. He said, "We decided to join negotiations with member states over the TPP," and said, "Japan should tap into the growing power of the Asia-Pacific region to hand down to future generations the affluence of our country as a trading nation."

After taking over the regime from the Democratic Party of Japan (DJP), the president of the Liberal Democratic Party (LDP) and new Prime Minister Shinzo Abe said, "If we only focus on protecting domestic agriculture, the Japanese economy will never get long-term development. The TPP is a platform that will lead Japan's economic leap in Asia-Pacific countries." Following this statement, he promised to give priority to agricultural problems and resisted the pressure from the LDP and domestic opposition. He also announced the official entry of Japan into the TPP negotiations on 15 March 2013.

\section{The Controversy of the TPP Negotiation in Japan}

The Japan Business Federation and Ministry of Economy, Trade and Industry of Japan believe that it will be helpful for Japan to expand the exports of Japanese cars, televisions and other traditional advantage products in the TPP system. It has calculated that if Japan joins the TPP, the GDP will increase by 2.4-3.2 trillion yen, and the annual growth rate could increase by $0.48 \%-0.65 \%$. If Japan does not join the TPP, by 2020 , the industrial production will decrease by 10.5 trillion yen, and 812,000 workers will lose their jobs. The GDP will also decline by $1.53 \%$.

The Japan Agricultural Co-operation (JA) and Ministry of Agriculture, Forestry and Fisheries (MAFF) strongly oppose Japan in joining the TPP negotiations because they believe and calculate that if Japan joins the TPP, the agricultural production will decrease by 4.1 trillion yen, and self-sufficiency rate of grain will decline from $40 \%$ to $14 \%$. Agricultural versatility will lose 3.7 trillion yen; GDP will decline by $1.6 \%$. Agricultural employment will decrease to 3.4 million people, and farmland will decrease from 4.6 million to 2.3 million hectares.

On the other hand, domestic scholars are divided on this issue; one group is supportive while the other opposes the idea of Japan joining the TPP. The scholars

3 Nobuto Iwata, "Research Article: Japan's Contribution to East Asian Community and TPP," Japanese Studies Journal Special Issue : Regional Cooperation for Sustainable Future in Asia, 2012, pp 45-48. 
who belong to the supportive group believe that Japan will promote agricultural reform through the TPP; this will lead to improvement in agriculture production, and enhance the competitiveness of Japan's agriculture sector. The most important reform of the agriculture sector is promoting transfer of part-time farmers' land to full-time farmers, to realize the agricultural scale operation. It is possible not only to expand the diversity of food imports to ensure the food security but also to expand the export of Japan's high quality agricultural products. However, the scholars who belong to the opposed group believe that low self-sufficiency rate of grain will lead to deterioration of the agriculture output in the rural areas. Moreover, the idea of promoting agricultural reform by joining the TPP implementation is considered too childish, and the Japanese government does not have enough budget to subsidize the farmers in the country.

\section{Japan's agricultural problems}

The most difficult issue of Japan's TPP negotiation is that of the agriculture sector, and Japan has tried to accelerate the domestic agricultural reform through the TPP. Therefore, the present status and issues of the Japanese agriculture sector will be discussed from the perspective of self-sufficiency rate of food, the decline in farm population and labor force, and the change potentially experienced by the Japanese farmers based on these three aspects.

\section{Low Self-sufficiency}

Japan is an island country with a population larger than its land area. It is an indisputable fact that a lack of natural resources has led to its low self-sufficiency rate of food. Table 1 shows the change in food self-sufficiency in Japan after the Second World War. First, measured by calories, Japan's highest food self-sufficiency rate was 73\% in 1965, but fell to $39 \%$ in 2011, which was declining year by year. Second, measured by output, Japan's highest food self-sufficiency rate was $86 \%$ in 1965, dropped to the lowest level of $65 \%$ in 2008, which recovered to $70 \%$ in 2009, but dropped to $67 \%$ in 2011 again. Therefore, even if Japan does not join the TPP negotiations, the food self-sufficiency rate will be on a continuous decline not only in terms of calories but also output.

Table 1: The change in Self-Sufficiency Rate of Food in Japan (Unit: \%)

\begin{tabular}{cccccccc}
\hline & 1965 & 1975 & 1985 & 2008 & 2009 & 2010 & 2011 \\
\hline Calories & 73 & 54 & 53 & 41 & 40 & 39 & 39 \\
\hline Output & 86 & 83 & 82 & 65 & 70 & 69 & 67 \\
\hline
\end{tabular}

Data source: Food Balance Sheet

(The Ministry of Agriculture, Forestry and Fisheries, Japan)

http://www.maff.go.jp/j/tokei/sihyo/data/02.html

According to the calculation by the MAFF, if Japan joins the TPP, the self-sufficiency rate of food will decline from $40 \%$ to $14 \%$; however, this calculation is questionable since Japan does not take any measures to protect its agriculture. For a self-sufficiency rate of food, Japan has always been focusing on the calorie standard, but other developed countries are oriented towards the output standard. Therefore, in Table 1, Japan's highest 
self-sufficiency rate of food in output was $86 \%$ in 1965 , even though it declined to $67 \%$ in 2011, which was also much higher than the calorie standard. The Japanese scholars who agreed Japan should join the TPP negotiations argued that the self-sufficiency rate of food, of course, the higher the better; nevertheless, food security should be ensured by a diversified and stable supply. It is important to identify the country that is given the priority to export food to Japan. Japonica rice is the staple food in Japan, so the food security in Japan is supported by the stable japonica rice supply. MAFF worries that Japan's domestic rice market would collapse due to competition from the cheaper American japonica rice.

On the other hand, according to the analysis of Professor Ito Schoichi, Kyushu University in Japan, the Chinese japonica rice has strong competitiveness in both flavor and price compared with the American japonica rice. First, the price of American japonica rice is $\$ 800$ per ton, but Chinese japonica rice is only $\$ 500$ per ton. Second, in terms of flavor, the japonica rice produced in northeastern China is a favorite, especially among the Japanese people because both rice technology and breeds are from Japan. The other important reason is the geographical factor; the distance from China to Japan is much nearer than that from the United States. This advantage saves transport time and transport cost; therefore, China's japonica rice is a good choice for Japan. ${ }^{4}$ At the same time, domestic rice producers in Japan should aim to make inroads into overseas markets of emerging countries. For example, the exports of high-quality Japanese rice to China are increasing, which is a significant source of income to the rice industry in Japan.

\section{Decline in Farming Population and Labor Force}

From 1960 to 1980, Japan experienced twenty years of rapid economic growth. As a result, the manufacturing industry provided more employment opportunities and higher wage income than agriculture. As a result, the population of farmers decreased sharply due to a large number of the population moving from rural to urban areas. As shown in Table 2, the Japanese farm population declined by $60 \%$ from 15.6 million in 1985 , to 6.5 million in 2010. However, farmers aged over 65 decreased only 0.4 million, and meanwhile the percentage of farmers aged over 65 rose from $16.9 \%$ to $34.3 \%$. On the other hand, the agricultural labor force also decreased from 5.4 million in 1985 to 2.6 million in 2010. The more serious problem posed was that laborers over the age of 65 years increased from 1.4 million in 1985 to 1.6 million in 2010; the corresponding percentage increased from $26.6 \%$ to $61.6 \%$. It is said that more than half of the Japanese agricultural labor force consists of mainly farmers over the age of 65 years, and the lack of successors has led to high costs of Japan's agricultural products. Moreover, Japanese farmers are protected by the government subsidies and high taxes, which cause the Japanese agriculture sector to lag behind in terms of international competitiveness.

4 Katsuya Yaguchi, "TPP and Japanese Agriculture: The Argument of Agricultural Policy", Nasional Library of Congress, Issue Brief No. 703, 2011, pp 1-10 (In Japanese). 
Table 2: Change of Japanese farm population and labor force

\begin{tabular}{lcccccc}
\hline & & \multicolumn{3}{c}{ (Unit: thousand population) } \\
\hline Farm & 1985 & 1990 & 1995 & 2000 & 2005 & 2010 \\
population & 15,633 & 13,878 & 12,037 & 10,467 & 8,370 & 6,503 \\
aged 65 & 2,643 & 2,709 & 2,904 & 2,936 & 2,646 & 2,231 \\
Rate (\%) & 16.9 & 19.5 & 24.1 & 28.0 & 31.6 & 34.3 \\
\hline Workforce & 5,428 & 4,819 & 4,140 & 3,891 & 3,353 & 2,606 \\
aged 65 & 1,443 & 1,597 & 1,800 & 2,058 & 1,951 & 1,605 \\
Rate (\%) & 26.6 & 33.1 & 43.5 & 52.9 & 58.2 & 61.6 \\
\hline
\end{tabular}

Data source: $\lceil$ Agricultural and Forestry Survey $\rfloor$

http:/ / www.maff.go.jp/j/keiei/kourei/senior/s_toukei/

\section{The Change of Full-time and Part-time Farmers}

Japanese farmers are divided into two categories: self-sufficient farmers and sales farmers depending on whether they sell their agricultural products or not. The sales farmers are further divided into full-time farmers and part-time farmers according to the working time on agriculture. The part-time farmers are then divided into the firstkind and the second-kind farmers according to the different levels of household income from agriculture. Table 3 shows that the population of Japanese farmers declined from 3.8 million in 1990 to 2.5 million only in 2010. Among them, sales farmers decreased by $45 \%$ from 2.9 million in 1990 to 1.6 million in 2010, full-time farmers only decreased by 22,000 , but part-time farmers dropped by 1.3 million at the same time. On the other hand, the number of non-farmers with land has greatly increased from 775,000 in 1990 to 1.4 million in 2010.

Table 3: Change of full-time and part-time farmers

\begin{tabular}{|c|c|c|c|c|c|c|}
\hline & & & & & (Unit: & lousan \\
\hline Total farr & & 1990 & 1995 & 2000 & 2005 & 2010 \\
\hline Tolar Ian & & 383.5 & 344.4 & 312 & 284.8 & 252.8 \\
\hline & Full-time & 47.3 & 42.8 & 42.6 & 44.3 & 45.1 \\
\hline Sale & Part-time & 249.8 & 222.3 & 191.1 & 152 & 118 \\
\hline farmers & First-kind & 52.1 & 49.8 & 35 & 30.8 & 22.5 \\
\hline & Second-kind & 197.7 & 172.5 & 156.1 & 121.2 & 95.5 \\
\hline Non-farm & vith land & 77.5 & 90.6 & 109.7 & 120.1 & 137.4 \\
\hline & Sales farmers & 77.5 & 77.0 & 74.9 & 68.9 & 64.5 \\
\hline & Full-time & 12.4 & 12.5 & 13.7 & 15.6 & 17.8 \\
\hline Rate (\%) & Part-time & 65.1 & 64.5 & 61.2 & 53.3 & 46.7 \\
\hline & First-kind & 13.5 & 14.5 & 11.2 & 10.8 & 8.9 \\
\hline & Second-kind & 51.6 & 50.0 & 50.0 & 42.5 & 37.8 \\
\hline
\end{tabular}

Note:(1) The first-kind of part-time farmer means that the agricultural income is the main source of household income.

(2)The second-kind of part-time farmer means that the agricultural income is not the main source of household income.

Data source: 「Agricultural and Forestry survey」

http://www.maff.go.jp/j/tokei/sihyo/data/07.html 
Land in Japan is privately owned, but the household income from the small-scale agriculture is insufficient to support a family. Therefore, most Japanese farmers choose to become part-time farmers, especially the second-kind farmers. Moreover, land is a valuable resource; the use of land is not restricted to agriculture after the farmers retire, but they can sell the land as a homestead or commercial land at a higher price. Therefore, the difficulty in grouping farm lands in a locality for agricultural purpose is the main reason for the inability of Japan's agriculture sector to achieve large scale of operations. Hence, one purpose of Japan joining the TPP negotiations is opening up the domestic market of agricultural products. Meanwhile, the Japanese government will introduce support or subsidy policies to promote part-time farming and encourage scattered farmers to transfer their land to full-time farmers, who have the ability to consolidate different plots of land for large-scale and efficient operations.

\section{Abeconomics and TPP}

Abeconomics is a series of economic policies introduced by Shinzo Abe since he became Japan's Prime Minister in December 2012. The focus of Abeconomics is the "monetary policy of quantitative easing." It led to the substantial depreciation of the Japanese yen in relation to the US dollar, which gave a great advantage to Japanese automakers who once suffered from the effects of a stronger yen. Thanks to the cheaper yen, Toyota and other seven car companies chalked up large amounts of profits in 2012. For example, Toyota achieved a net profit growth of 3.7 times, to 1.3 trillion yen, becoming the most profitable car company in the world. Honda also attained 2.4 times profit, and Mitsubishi's net profit increased by $58.7 \%$ in 2012. One of the most important purposes of Japan joining the TPP negotiations is to expand the markets for its exports, such as automobiles, machinery, and precision instruments. In view of these benefits, Abeconomics was seen as paving the way for Japan's big enterprises to export their products.

Besides the monetary policy of quantitative easing, increasing the consumption tax is another important method of Abeconomics. The present consumption tax is $5 \%$ and will be increased to $8 \%$ from April 2014, followed by further increase from $8 \%$ to $10 \%$ in 2015 . The main purpose of hiking the consumption tax is to increase the government's financial income, so that it can maintain the income subsidy policy for Japanese farmers. At the same time, MAFF is also actively exploring the income insurance policy for farmers, which will ensure a minimum sales income when the prices of rice, vegetables and other agricultural products drop substantially. This step of market intervention helps to provide risk management for farmers, and to build a stable safety net for agricultural management.

The biggest concern of Japan in the TPP negotiations in agriculture is the impact of cheaper foreign agricultural products on five areas, including rice, wheat, beef-pork, milk products and sugar. These five areas in Japan are known as "the Saint Area," which is related to the Japanese agriculture survival, and is the bottom line of Japanese agriculture. High tariff measures have always been used by the Japanese government to protect these five areas. For example, rice tariffs are set as high as $778 \%$, and wheat tariffs are more than $252 \%$. These five areas are also divided into related agricultural products of more than 586 items. The principle of Japan's EPA negotiations with other countries is reducing and canceling tariffs for foreign agricultural products, which have no impact on these five areas. On the contrary, if the foreign agricultural products will 
impact these five areas, Japan's attitude is to practice exceptional handling and avoid reduction in the tariffs. Therefore, Japan's attitude toward negotiations of agricultural products has been cautious and conservative.

In the past, Japan's EPA negotiations were on a small scale, mostly dealing with the developing countries, and the trading of agricultural products between these countries and Japan. Japan frequently uses the same negotiation skills to protect its own agricultural products, avoiding the side effects of imports on its domestic products and to expand the export of Japanese traditional products. However, things have changed after Japan's TPP negotiations with two developed countries, the United States and Australia. Both the United States and Australia require Japan to cancel all the tariffs for agricultural products, and it is clearly impossible for Japan to accept this request. Nevertheless, the Japanese government promised to reduce $93.5 \%$ of tariffs on agricultural products except those products sold in the five areas; rice tariffs will be cut from $778 \%$ to $500 \sim 600 \%$. Japan hopes that the United States will give Japan 10 years for agricultural reform. However, it is obviously impossible for America to accept this request. Japan uses the same strategy both in the EPA and TPP negotiations for agriculture; however, from the viewpoint of the United States, Japan cannot only enjoy the benefits from its product exports. It must be ready to fully open up its domestic market of agricultural products, which is also part of the principles and obligations as a TPP member.

\section{Conclusion}

One of Japan's agricultural calculations of the TPP negotiations is continuing to use the high tariffs method to protect important domestic agricultural areas. The other calculation is promoting and accelerating the domestic agricultural reform though the TPP negotiations. However, the principle of TPP is to eliminate tariffs completely among member states without exceptions. It is different from Japan's EPA negotiations in that, Japan is a leading country when it negotiates with developing countries. However, in the TPP negotiations, the United States is the leading country, and the negotiation rules are different. If Japan wants to join the TPP as soon as possible, it must open up its domestic market of agricultural products immediately. After analyzing the present status of Japan's agriculture sector, there will be no advantage if Japan does not join the TPP; Japan will still face problems of low self-sufficiency rate of food, decrease in farm population and the labor force, and increase in the number of farmers over the age of 65. The Liberal Democratic Party (LDP) of Japan can regain power if it can garner the support of Japanese farmers; therefore, the LDP cannot ignore the interests of JA and many small-scale farmers. As long as the United States insists on the principle of full elimination of tariffs, it will be difficult for Japan to join the TPP as soon as possible. Unless Japan accepts the conditions, the Japanese regime may see a change again. 
